\title{
Why do firms go public through debt instead of equity? *
}

\author{
Denys Glushkov \\ Acadian Asset Management \\ Ajay Khorana \\ Citigroup \\ P. Raghavendra Rau \\ University of Cambridge \\ Jingxuan Zhang \\ University of Cambridge
}

May 2018

\begin{abstract}
We analyze a sample of private firms that go public through an initial public debt offering (IPDO) as an alternative to going public through equity (IPO). Firms that choose the IPDO route are larger, more likely to be backed by a financial sponsor such as a venture capital or private equity firm, and less likely to face information asymmetry than traditional IPO firms. Only a quarter of these firms eventually conduct an IPO, but those who do face lower underpricing than their contemporaneous private peers who do not have public debt at the time of going public.
\end{abstract}

Keywords: Initial public debt offerings, information asymmetry, going public decision, financial statement informativeness

JEL Codes: G32

\footnotetext{
*Glushkov: Acadian Asset Management, USA (e-mail: dglushkov@acadian-asset.com); Khorana: Citigroup, USA (email: ajay.khorana@citi.com) Rau and Zhang: University of Cambridge, Judge Business School, Trumpington Street, Cambridge CB2 1AG, UK (email: r.rau@jbs.cam.ac.uk; jz428@jbs.cam.ac.uk).We would like to thank Robyn Banks, Amit Bubna, François Derrien, Dirk Hackbarth, Bart Lambrecht, Jay Ritter, Chip Ryan, Tony Saunders, Anil Shivdasani, Avanidhar Subrahmanyam, Bob Waldman, Ivo Welch (editor), and seminar participants at the 2013 European Finance Association meetings, the 2013 ISB Summer Research Conference in Finance, the 2012 TAPMI Conference on Finance and Economics, Cass Business School, Imperial College, the University of Glasgow, and the University of Oxford for helpful comments and the Cambridge Endowment for Research in Finance (CERF) for financial support. The main part of the paper was written while Denys Glushkov was at Wharton Research Data Services (WRDS).
} 


\title{
Why do firms go public through debt instead of equity?
}

\begin{abstract}
We analyze a sample of private firms that go public through an initial public debt offering (IPDO) as an alternative to going public through equity (IPO). Firms that choose the IPDO route are larger, more likely to be backed by a financial sponsor such as a venture capital or private equity firm, and less likely to face information asymmetry than traditional IPO firms. Only a quarter of these firms eventually conduct an IPO, but those who do face lower underpricing than their contemporaneous private peers who do not have public debt at the time of going public.
\end{abstract}

Keywords: Initial public debt offerings, information asymmetry, going public decision, financial statement informativeness 


\section{Introduction}

Extant literature typically describes the going public process as involving private firms choosing to go public through an equity issuance - an initial public offering (IPO), a process that allows the owners to exit. ${ }^{1}$ The theoretical and empirical literature has neglected the possibility of firms choosing to go public through a debt issuance - an initial public debt offering (IPDO). ${ }^{2}$ Yet, as an available option, it could also affect the IPO choice. Selection biases in the type of firms choosing the equity market IPO could influence the results in the IPO market literature.

In this paper, we document the relative importance of the IPDO process and examine characteristics of firms that choose to go public through debt rather than equity. Our sample consists of 635 hand-collected IPDOs from 1987 to 2016. We compare these firms to contemporaneous IPO firms to analyze why these firms choose to go public through the debt market.

Over our sample period, $18 \%$ of going public firms chose to access public markets through public debt, while $82 \%$ chose to access the equity market. Controlling for industry and year, the total amount raised is around $45 \%$ of that raised through IPO issues. Around a quarter of our IPDO firms eventually issued equity. The average time lag between the IPDO and the subsequent IPO is over two years, similar to that in Welch (1989) for seasoned offerings following the IPO.

Theory suggests that the choice of venue depends on three factors: (1) the costs of information production, (2), the value of a liquid currency, and (3) the value of private benefits of control. First, going public, whether through debt or equity, involves disclosing the same level of information

\footnotetext{
${ }^{1}$ There are only a handful of papers analyzing the going public decision. They include Lerner (1994) who studies the timing of IPOs in a sample of privately held biotechnology firms, Pagano, Panetta, and Zingales (1998), Fischer (2000) and Aslan and Kumar (2011) who study the decision to go public in Italy, Germany, and the U.K. respectively, Bancel and Mittoo (2009) who survey European Chief Financial Officers (CFOs) on the determinants of their going public decisions, and Helwege and Packer (2009) and Chemmanur, He, and Nandy (2010) who study firms' decisions to go public in the U.S.

2 Papers that examine the first issue of bonds by public and private firms largely focus on explaining the underpricing once the firm has already made the decision to choose a particular market. Examples include Datta, Iskandar-Datta, and Patel (2000) who show that in contrast to seasoned debt offering announcements, the initial public debt offering by a publicly listed firm has a negative impact on shareholder value, Berkovitch, Gesser, and Sarig (2005) who do not examine the going public decision itself but compare the equilibrium characteristics of private firms with public debt to public firms and document that firms with public equity in place but no public debt tend to have a higher R\&D intensity, Cai, Helwege, and Warga (2007) who examine underpricing outcomes in the corporate bond market, and Saunders and Steffen (2011) and Kovner and Wei (2011) who document that private firms are substantially disadvantaged in the debt market compared to public firms.
} 
through similar financial statements. ${ }^{3}$ Ball, Robin, and Sadka (2008) argue that, like equity markets, debt markets utilize both financial-statement and other information in pricing decisions, at issuance and in the secondary market. However, debt differs from equity in that many of the post-issuance contractual rights of lenders are written in terms of financial statement variables alone. Reported financial statements can affect various covenanted financial ratios (balance sheet leverage and earnings-based interest coverage ratios), and dividend and stock repurchase restrictions. Other information that is not reflected in the financial statements does not affect those rights. In contrast, shareholders are comparatively less interested as to whether gain and loss information is reflected in the financial statements or received via non-financial disclosure, so long as they receive it. Hence firms that are more easily able to disclose their important performance data through financial statements have a relative advantage in the debt market. Second, an equity issue exposes them to a risk of a loss of private benefits of control. Third, going public through equity also allows managers to create a liquid currency to carry out other transactions. That is not the case with debt. Our hypotheses and variables are summarized in Table 1.

To obtain our IPDO sample, we start by examining firms that issue public securities for the first time. Section 15(d) of the Securities Exchange Act of 1934 that mandates that firms that issue public securities of any type are required to file an annual report during the fiscal year within which the public security registration statement became effective, as long as at the beginning of that year, they had more than 300 security holders on record, and regardless of whether they have publicly traded equity or not. ${ }^{4}$ We hand-collect financial statement data on private firms that issue public debt without having public equity in place and compare this unique hand-collected IPDO sample to traditional IPOs with no public debt outstanding. We perform two sets of comparisons: (1) matching firms on industry and year to control for variations in the level of market and industry sentiment that have been shown to influence the level of security issuance (Baker and Wurgler, 2002), and (2) matching firms on industry, year, and firm assets to control for size, although the sample size shrinks in the latter case.

IPDO firms are not concentrated in any particular industry. Private firms issue public debt in 43 industries (based on the Fama-French 48 industry classification). However, controlling for

\footnotetext{
${ }^{3}$ The direct costs of going public are similar for both markets. Sankaraguruswamy and Whisenant (2009) estimate initial audit fees on the order of about \$1 million for the average firm listed on Audit Analytics from 2000-2007. Private firms that issue public financials are even rarer.

${ }^{4}$ See pp. 172-173 of Securities Exchange Act of 1934, https://www.sec.gov/about/laws/sea34.pdf
} 
industry, year, and size, there are significant differences between IPDO and IPO firms. IPDO firms typically exhibit superior operating performance, spend less on research and development, have higher ratios of operating cash flows to capital expenditure, and have more private debt than IPO firms. In other words, IPDO firms appear to be more established firms whose assets are relatively more amenable to financial statement analysis. They are also more likely to be backed by a financial sponsor such as a venture capital or private equity firm, suggesting that ownership structure also matters. However, an industry liquidity index that measures the level of corporate transaction activity, is largely unrelated to the probability of an IPDO, suggesting that creation of a liquid currency is not a factor in the choice of venue.

There are also significant differences between IPDO firms and public firms that issue debt for the first time (PFDO) in the same industry and year. IPDO firms are older, are more likely to be sponsor-backed, have better operating performance, similar growth opportunities, and lower liquidity than PFDO firms. They also face a significantly higher cost of debt (offer yield), more restrictive covenants, and lower credit ratings than the PFDO firms.

$16 \%$ of the IPDO sample subsequently issue equity through an IPO, without issuing any additional public debt prior to the IPO. Another $11 \%$ access the public debt market at least once more before issuing public equity. By the end of our sample period in 2016, while a significant number of firms end up being acquired (23\%), only a relatively tiny proportion of firms (1\%) go bankrupt or are liquidated, or go private again (2\%).

Welch (1989) argues that underpricing at the IPO results in a higher price at a seasoned offering. If the same mechanism holds for debt offerings, IPDO firms may earn better terms at a subsequent public debt or equity offering. For the firms that issue public debt again following the IPDO, the subsequent offering is larger and indeed has a lower offer yield. This result continues to hold in a multivariate framework, where after controlling for year fixed effects, leverage, the terms of the debt, the offer yield is lower for the subsequent issue of public debt by the IPDO firms relative to their first issue of public debt. After adding controls for firm and covenant characteristics, however, the difference in offer yield is no longer significant. After a firm has filed formal financial statements while going public, there appear to be fewer benefits for subsequent issues.

$27 \%$ of our IPDO sample subsequently choose to raise public equity. For these firms, the initial higher cost of debt at the IPDO does appear to be offset by lower underpricing at the time of the 
eventual IPO. The median IPO underpricing (proxied by the first day return) for our sample of IPDO firms that chose to eventually issue public equity is less than a third that of matching IPO firms issuing public equity with no prior public debt in place; the amount raised through the offering is double; and the fees charged by the equity underwriters are lower. Controlling for firm size, age, operating performance, industry, and time, an IPDO indicator variable is significantly negatively related to the level of underpricing in the issue.

In sum, our paper shows that ownership structure and the relative cost of information production are significant factors dictating the choice of venue in going public. Future IPO research should take into account that firms do not just face a choice between going public and staying private, but also an intermediate choice of issuing public debt but staying private.

\section{Data Sources}

We obtain issuance data from Thomson-Reuters SDC Platinum (for both public debt and equity) and Mergent FISD (for public debt). Credit ratings that are not available in SDC and FISD are supplemented by data from S\&P Ratings Xpress and Datastream. Fundamental firm data is obtained from Compustat, and price/return data are obtained from CRSP, Compustat North America, and Compustat Global security pricing files. Our sample covers a total of 635 IPDO issuers from 1987-2016. We start in 1987 because bond data is sparse before $1987 .^{5}$ The Appendix (in the main text) describes our matching procedure briefly and the online Appendix goes into more detail.

For the purposes of comparison, we form two control samples: (1) firms that issue public equity via an IPO without having any public debt outstanding (2,963 equity IPOs) and (2) publicly listed firms that tap the public debt market for the first time (PFDO firms) (897 issuers) respectively. Both sets of controls are matched on the sample firm's industry (using the Fama-French 48 industry classification) and year. ${ }^{6}$ We also match on industry, year, and size, though this sample size is smaller. Finally, to investigate if IPDO firms have better deal terms during their first equity issuance (IPO) that follows the initial public debt offering, we use the SDC equity issues database

\footnotetext{
${ }^{5}$ Less than $2.5 \%$ (3\%) of all FISD (SDC) bond issues are recorded with an issue year prior to 1987.

${ }^{6}$ In untabulated robustness tests, we compare the IPDO firms with publicly listed firms that have public debt outstanding and issue additional public debt subsequently in the same industry and year (909 issuers). Our results are qualitatively similar to those documented for PFDO firms and hence we discuss only the PFDO comparison in the text.
} 
to identify 171 IPDO firms that eventually went public by issuing public equity in our analysis period between 1987 and 2016.

\section{Characteristics of IPDO firms}

\subsection{Are IPDO firms significant in terms of raising capital?}

Table 2 shows the time series issuance patterns of our sample of unlisted IPDO firms and compares them to two industry-year and industry-year-size matched IPO control samples, plus one publicly-listed firm debt-issue control sample, also matched on industry and year. In the industryyear-size matched sample, we constrain the matched industry-year IPO firms to have total assets at least as large as the IPDO firm. The final PFDO control sample consists of listed firms that issue public debt for the first time.

Over the 1987-2016 period, 635 private firms choose to tap the public debt market for the first time (there are no IPDO firms in 2008 and 2009), a number similar to those by PFDO firms (897). Not surprisingly, the number of firms issuing public debt is highly correlated over time across the IPDO and PFDO control samples, with a coefficient of correlation of 0.89 . The IPDO sample is a non-trivial proportion (around 20\%) of all IPO firms that issue equity in the same industry and year, with 2,963 (850) industry-year matched (industry-year-sized) matched IPO firms respectively. Figure 1 illustrates these patterns graphically. The correlations between the IPDO sample and the two IPO samples are positive and significant at 0.71 and 0.47 respectively, suggesting that while there is a significant time-series component to when firms tap the capital markets, the choices of venue are based on cross-sectional differences in the firms.

Next, we test the alternative hypothesis that firms self-select into the IPDO and IPO markets based on time-series factors in financing, not on cross-sectional characteristics. For example, the IPO market was relatively cold between 2001-2003. If selection is based on time-series factors that affect the cost of financing, firms that chose an IPDO would be more likely to continue with an equity offering immediately after equity market activity increased after 2004 . However, tracing the history of these firms (not reported in the tables) shows no significant variations in changes in equity issuance activity following either cold or hot markets. Firms do not appear to self-select into public markets based on the time-series of returns. They also do not appear to choose IPDOs because there are no peer IPOs. 
IPDO firms also raise significantly more capital each time they tap the capital markets through debt financing than their industry-year matched equity IPO counterparts. While the aggregate amount of debt issued for the IPDO sample is less than half the value of equity raised via an IPO - \$87 billion and \$194 billion, respectively - the average IPDO firm raises \$264 million of capital versus $\$ 49$ million for the average industry-year matched IPO. The numbers for the industry-yearsized matched IPO sample is roughly comparable to the IPDO sample.

\subsection{Comparing IPDO and IPO firms}

We report univariate comparisons between the IPDO and the two IPO samples in Table 3. The ownership structure differs significantly between the IPDO and the IPO samples with a sponsor involvement in $70 \%$ and $48 \%$ (55\%) of the IPDO and industry-year matched (industry-size-year matched) IPO firms respectively. Turning to firm characteristics, IPDO firms are significantly older and larger than their IPO counterparts. IPDO firms have a median age of 10 years at issuance versus 5 years for both the industry-year matched and industry-year-size matched IPO samples, each. The median IPDO firm also has total assets of $\$ 382$ million which is significantly larger than the $\$ 91$ million for the median industry-year matched IPO firm and the $\$ 163$ million for the industry-year-size matched firm. Finally, IPDO firms have significantly higher ratios of industryadjusted operating cash flow to capital expenditure to their size-matched IPO counterparts, suggesting that they do not need to raise significant amounts of external capital to finance their investments. These results are consistent with the hypothesis that debt markets might be more willing to supply credit to older, more established firms with lower financial distress costs - firms where financial statement information is relatively important in establishing value.

This hypothesis also appears to explain our results on operating performance. Operating performance, as proxied by industry-median adjusted operating ROA, is significantly higher for the IPDO firms, with values of 0.01 relative to $-0.09(-0.04)$ for the industry-year (industry-yearsize) matched IPO firms. Proxies for growth opportunities, as measured by the ratios of R\&D to assets, are significantly lower for the IPDO firms than for their IPO controls. Finally, industryadjusted leverage metrics are significantly higher for the IPDO sample than for the industry-year matched IPO firms, Overall, these results are consistent with the view that those firms with lower investment needs, greater transparency about the underlying asset base, and larger size, are more likely to access public debt markets. 
Liquidity metrics, proxied by the current, quick, and cash ratios, are the one dimension where the IPDO firms display a significant worse picture than IPO firms. Current, quick, and cash ratios are all significantly lower than their equity first counterparts. This is not entirely surprising. To the extent that IPO firms are likely to exhibit greater earnings variability emanating from higher embedded growth options, one would expect these firms to maintain higher liquidity levels to manage tail risk on the balance sheet.

In Table 4, we examine the capital raising choice in a logit regression framework. Specifically, the dependent variable takes the value 1 if it corresponds to an observation in our primary IPDO sample and 0 for the industry-year matched (models 1-5) and industry-year-size matched (model 6) IPO samples. While we do not specifically control for macro-economic characteristics that affect the decision to issue since our sample firms are matched to the control sample by industry and year of issuance (and size), we still include year fixed effects to alleviate the concern that this match may not fully control for all the differences. We report coefficients for a restricted subset of the variables in Panel A to avoid multicollinearity issues. However, we note our results are robust to using the alternative variables.

Most of our variable choices are driven by the findings of Chemmanur, He, and Nandy (2010) who find that size, age, and private funding (sponsor-backing in our sample) are important determinants of the decision of the firm to go public using equity. Beyond the measures in Table 3 , we include the level of industry misvaluation to proxy for the existence of windows of opportunity (market timing behavior) (Baker and Wurgler, 2002). We also control for a number of market-specific underpricing factors and costs. Equity underpricing is the median first day return of all equity IPOs in the respective Fama-French industry in a given month, while debt underpricing is the 12-month moving average of industry-level median of abnormal individual bond IPO and SEO returns (in excess of the return on the corresponding bond index) over the 7 days from the offering date. Equity underwriting cost is the mean gross spread per share of all equity IPOs in the respective industry in a given month. Debt underwriting cost is the 12-month moving average of the industry-level mean gross spread in a given month. Finally, we also include an industry liquidity index, (calculated as in Schlingemann, Stulz, and Walkling, 2002), as the ratio of the value of corporate control transactions to the total book value of assets of firms in a given industry-year. The index proxies for the value of having equity as a liquid currency to buy other assets. 
Our results in columns 1-5 are broadly consistent with the univariate results: size ((log) assets), age, asset tangibility (PPE/assets) and prior leverage are significantly positively related to the probability that a private firm chooses an IPDO over an IPO. The coefficients in Model 6, which contrasts the IPDO sample to the industry-year-size matched IPO sample, yield similar inferences to models 1-5. Controlling for firm-level and market-level determinants, sponsor-backed private firms are significantly more likely to issue public debt in preference to equity, consistent with the hypothesis that these investors value private benefits of control. The industry liquidity index is largely unrelated to the choice of an IPDO suggesting the creation of a liquid currency does not play a significant role in the choice of market. Finally, there is little evidence that misvaluation plays a role in the IPO market. The level of industry misvaluation and the level of equity and debt underpricing is unrelated to the choice of an IPDO.

We note that our results contrast with those in Chemmanur, He, and Nandy (2010) in that they find that several factors (notably size and age) are significantly positively related to the decision to issue equity. In contrast, we find that size and age are significantly stronger determinants in the choice of issuing public debt in preference to equity.

\subsection{Comparing IPDO and PFDO firms}

Table O-1 in the online appendix compares the private IPDO firms to PFDO firms, publicly listed firms that are issuing debt for the first time. Both these samples comprise firms accessing the public debt markets for the first time in the same year and the same industry, with the major difference being the public status of the latter. Hence, there is likely to be a significantly greater amount of information available for the latter firms. While the contrast between the IPDO firms and the PFDO firms is less dramatic than between the IPDO and IPO firms, the general pattern is roughly similar. IPDO firms continue to be significantly more likely to be sponsor-backed and have characteristics that make their formal financial statements more informative than firms that choose to raise debt after going public.

Panel A of Table O-1 shows that IPDO firms are comparable to their PFDO counterparts. Sizes (assets) are similar, though sales are larger. The IPDO firms are significantly older than their PFDO counterparts. Operating cash flow/Capex and operating ROA are both significantly better than the comparable PFDO firms. However, growth opportunities and leverage are similar. 
Panel B shows that not surprisingly, the lack of public status for the IPDO firms translates into worse terms at the debt offering. While the size of the debt offering is similar for IPDO firms and PFDO firms, the offer yield and coupon are both significantly higher than the PFDO firms. The debt issued by the IPDO firms is more likely to be rated and to be investment grade. However, both Moody's and S\&P rate the debt as lower quality than the debt issued by PFDO firms. Finally, IPDO firms are significantly more likely to face restrictive covenants than their PFDO counterparts. They are more likely to offer secured debt and face borrowing restrictions, and restrictions on default, stock issuance, takeovers, and asset investment.

Panel C reports coefficients from a generalized least squares (GLS) regression with year fixed effects, where we compare offer yields for the IPDO firms to those for the PFDO firms in the same industry and year. The IPDO sample exhibits a 133 to 163 basis points of incremental offer yield (models 1-3), and the yield differential persists after controlling for various debt, firm, and covenant characteristics (models 4-6). Most firm characteristics do not appear to affect the offer yield. In particular, sponsor-backing does not appear to affect the offer yield. IPDO firms suffer relative to their listed counterparts at their first debt issue. In unreported tables, we also regress IPDO and PFDO indicators on the yields for the universe of bonds listed on FISD, controlling for time fixed effects. Both IPDO and PFDO firms pay significant higher yields on their debt than the universe but the premium paid for IPDO bonds over the PFDO bonds persists when we compare both to the universe.

\subsection{Subsequent behavior of IPDO firms}

We next examine the subsequent capital raising behavior of the 635 firms in our original sample of IPDO firms. Before the end of our analysis period in 2016, only around $11 \%$ of these firms access the public debt market again before issuing public equity, raising an additional $\$ 132.5$ billion in public debt and $\$ 13.9$ billion in public equity. A much larger number of firms, $16 \%$ of the IPDO sample, choose to tap the equity market subsequent to their public debt issue, without issuing any additional public debt prior to the IPO. The remaining IPDO firms in our sample choose to remain private until the end of 2016, raising an additional $\$ 552$ billion of capital via the public debt markets. In a sequential logistic framework (untabulated), we find that while sponsorbacked firms are significantly less likely to tap the capital markets again, the sponsor-backing variable loses its significance when we include macroeconomic characteristics. In particular, 
market return and industry misvaluation variables are weakly positively related while inflation (the CPI level) is weakly negatively related to the choice to tap the public markets again. Firm characteristics are largely unimportant with the exception of operating performance (ROA). IPDO firms with high operating performance are significantly less likely to tap the capital markets after going public.

Conditional on raising additional capital however, what determines the choice of whether to raise capital through equity or debt? Again, the most important determinants appear to be macroeconomic variables. Sponsor-backed firms are significantly less likely to tap the equity capital markets but their significance disappears once we once we include macroeconomic characteristics. The level of industry misvaluation is a strong predictor of the choice of equity for the subsequent capital raising decision, though this effect is to some extent mitigated for sponsor backed firms.

\subsection{Comparing subsequent debt issues of IPDO firms}

Welch (1989) argues that underpricing at the IPO acts as a signal of quality, resulting in a higher price at a seasoned offering. If the same mechanism holds for debt offerings, IPDO firms may earn better terms at a subsequent public debt or equity offering.

The signaling mechanism does not appear to work for debt largely because debt characteristics change significantly between the initial and subsequent issue. Table O-2 in the Online Appendix shows that the average offering size is significantly larger for the subsequent issue - $\$ 250$ million (versus $\$ 135$ million for the first debt issue) and the offer yield decreases by 200 basis points in the second issue. We also examine variability in the use of covenants and other restrictions across these two samples. Most covenants appear to tighten between the first issue and the subsequent issue, and the univariate differences are significant at conventional significance levels. In a multivariate framework, when we control for these firm and covenant characteristics, there appears to be no difference between offer yields for the initial issue of debt by IPDO firms and their

subsequent issues. They suggest that after the initial public issue, the additional information conveyed by the public status of these firms is largely irrelevant in comparison to the financial information disclosed in the reported financial statements of the firm. 


\subsection{Comparing subsequent equity issues of IPDO firms}

IPDO firms may benefit from lower underpricing at a subsequent equity issue, if any. ${ }^{7}$ In Table 5, we compare the IPO characteristics of firms tapping the public capital markets for the very first time via an IPO, with IPO firms which have outstanding public debt (our primary IPDO sample carrying out a subsequent IPO). Consistent with Welch (1989), IPO underpricing, as measured by first day returns for IPDO firms going public is significantly lower relative to the IPO sample: $15 \%$ versus 51\%. This suggests that on a percentage basis, the wealth transfer from issuing shareholders to the investing public is significantly smaller for those IPO firms who have previously tapped public debt markets - a surprisingly strong result - suggesting significantly less money left on the table for these firms. The offer price exceeds the original high filing price ("Hot" IPO indicator variable) in $71 \%$ and $73 \%$ of the IPDO and IPO samples, respectively. The lower proportion for the IPDO sample is consistent with lower information asymmetry and more stable operating metrics of larger and more established firms, as documented in the previous sections. Not surprisingly, given the reduced informational asymmetry via a more prolonged certification process for these firms and the lower observed underpricing, managers are more willing to raise additional capital - \$120 million versus $\$ 60$ million for the average IPDO and the IPO samples, respectively.

Table 6 provides results from a multivariate regression to explain the variability in IPO underpricing across the two samples. Some firm and IPO characteristics appear to affect the underpricing in economically sensible ways. For example, age is consistently negatively related to the level of underpricing. In models (2)-(4), we include additional controls for underwriter effort (the number of managers) and find a significant negative relation between the level of underpricing and underwriter effort. We do not find a consistently significant relation between underpricing and the fees charged by the underwriters. However, the key takeaway of Table 6 is that we continue to find a statistically significant $17-19 \%$ lower IPO underpricing for those firms who first tap public debt markets prior to undertaking an IPO after controlling for various IPO and firm characteristics - age, size, profitability, and liquidity.

\footnotetext{
${ }^{7}$ We note that Cai, Ramchand, and Warga (2004) also examine the public equity decision following the public debt decision. However, not all the firms that issue public debt subsequently issue equity. Our analysis so far examines the first going public decision without constraining the firm to have a subsequent equity issue.
} 
To control for a sample selection bias resulting from the initial choice of issuing either public equity or public debt for the first time, we also estimate a two-stage Heckman selection model (results not tabulated). In the first stage, we estimate an inverse Mills ratio based on the probit regressions in Table 4. The prior leverage of the firm is used as the identifying restriction in the first stage estimation procedure. ${ }^{8}$ This restriction is based on the assumption that the prior leverage of the firm is likely to be a factor in the firm's choice to issue either public equity or public debt for the first time (it is significant across all models in Table 4 and has been shown to be significant in papers examining the persistence of capital structure (see for example, Lemmon, Roberts, and Zender, 2008)). However, it is unlikely that this will directly affect the degree of IPO underpricing. In the second stage, we model IPO underpricing between two samples and control for the sample selection bias by including the previously estimated inverse Mills ratio. However, an insignificant coefficient on the inverse Mills ratio variable suggests that a potential cross-sectional selection bias does not influence our findings.

Overall, our findings are supportive of the idea that, ceteris paribus, firms with public debt in place tend to have lower underpricing relative to their industry-year matched counterparts.

\section{Conclusions}

In this paper, we analyze a sample of private firms that choose to go public through the debt markets as an alternative to the equity markets. These firms are typically significantly larger and less likely to have information asymmetry problems than traditional firms in the same industry and year. When the debt-first firms eventually go public by issuing equity, they face lower underpricing than firms without public debt that undertake an initial public offering in the same industry. Ownership structure (backing by a financial sponsor such as a venture capital or private equity firm) and the relative cost of information production in debt versus equity markets appear to be significant in explaining why these firms choose debt before equity and their subsequent decision to issue equity. Future research on IPOs should take into account that firms do not just face a simple choice between going public and staying private, but also an intermediate choice of issuing public debt but staying private.

\footnotetext{
${ }^{8}$ As an alternative instrument, we also use the need for external financing (OCF/Capital expenditure) based on Helwege and Liang (1996) who document that probability of obtaining external funds is unrelated to the shortfall in internally generated funds for a sample of firms that went public in 1983. However, our results and conclusions are qualitatively unaffected when we use this alternative instrument.
} 


\section{References}

Aslan, Hadiye, and Praveen Kumar, 2011, Lemons or cherries? Growth opportunities and market temptations in going public and private, Journal of Financial and Quantitative Analysis 46, 489526.

Baker, Malcolm P., and Jeffrey Wurgler, 2002, Market timing and capital structure, Journal of Finance 57, 1-32.

Ball, Ray, Ashok Robin, and Gil Sadka, 2008, Is financial reporting shaped by equity markets or by debt markets? An international study of timeliness and conservatism, Review of Accounting Studies 13, 168-205.

Bancel, Franck, and Usha R. Mittoo, 2009, Why do European firms go public?, European Financial Management 15, 844-884.

Berkovitch, Elazar, Ruth Gesser and Oded Sarig, 2005, Being a public company: Public debt or public equity, unpublished working paper, IDC Herzeliya.

Boot, Arnoud W. A., Radhakrishnan Gopalan, and Anjan V. Thakor, 2006, The entrepreneur's choice between private and public ownership, Journal of Finance 61, 803-836.

Boot, Arnoud W. A., Radhakrishnan Gopalan, and Anjan V. Thakor, 2008, Market liquidity, investor participation and managerial autonomy: Why do firms go private?, Journal of Finance 63, 2013-2059.

Cai, Nianyun, Latha Ramchand, and Arthur Warga, 2004, The pricing of equity IPOs that follow public debt offerings, Financial Management 33, 5-26.

Cai, Nianyun, Jean Helwege, and Arthur Warga, 2007, Underpricing in the corporate bond market, Review of Financial Studies 20, 2021-2046.

Celikyurt, Ugur, Merih Sevilir, and Anil Shivdasani, 2010, Going public to acquire? The acquisition motive in IPOs, Journal of Financial Economics 96, 345-363.

Chemmanur, Thomas J., and Paolo Fulghieri, 1999, A theory of the going-public decision, Review of Financial Studies 12, 249-279. 
Chemmanur, Thomas J., Shan He, and Debarshi K. Nandy, 2010, The going-public decision and the product market, Review of Financial Studies 23, 1855-1908.

Daniel, Kent D. and Sheridan Titman, 2006, Market reactions to tangible and intangible information, Journal of Finance, 61, 1605-1643.

Datta, Sudip, Mai Iskandar-Datta, and Ajay Patel, 2000, Some evidence on the uniqueness of initial public debt offerings, Journal of Finance 55, 715-743.

Fischer, Christoph, 2000, Why do companies go public? Empirical evidence from Germany's Neuer Markt, unpublished working paper, Ludwig-Maximilians-Universität Munich.

Helwege, Jean, and Nellie Liang, 1996, Is there a pecking order? Evidence from a panel of IPO firms, Journal of Financial Economics 40, 429-458.

Helwege, Jean, and Frank Packer, 2009, Private matters, Journal of Financial Intermediation 18, 362-383.

Hsieh, Jim, Evgeny Lyandres, and Alexei Zhdanov, 2011, A theory of merger-driven IPOs, Journal of Financial and Quantitative Analysis 46, 1367-1405.

Kovner, Anna, and Chenyang Wei, 2011, The private premium in public bonds, unpublished working paper, Federal Reserve Bank of New York.

Lemmon, Michael L., Michael R. Roberts, and Jaime F. Zender, 2008, Back to the beginning: Persistence and the cross-section of corporate capital structure, Journal of Finance 63, 1575-1608.

Lerner, Josh, 1994, Venture capitalists and the decision to go public, Journal of Financial Economics 35, 293-316.

Pagano, Marco, Fabio Panetta, and Luigi Zingales, 1998, Why do companies go public? An empirical analysis, Journal of Finance 53, 27-64.

Rhodes-Kropf, Matthew, David T. Robinson, and S. Viswanathan, 2005, Valuation waves and merger activity: The empirical evidence, Journal of Financial Economics 77, 561-603. 
Sankaraguruswamy, Srinivasan, and Scott Whisenant, 2009, Pricing initial audit engagements: Empirical evidence following public disclosure of audit fees, working paper, National University of Singapore.

Saunders, Anthony, and Sascha Steffen, 2011, The costs of being private: Evidence from the loan market, Review of Financial Studies 24, 4091-4122.

Schlingemann, Frederik P., René M. Stulz, and Ralph A. Walkling, 2002, Divestitures and the liquidity of the market for corporate assets, Journal of Financial Economics 64, 117-144.

Welch, Ivo, 1989, Seasoned offerings, imitation costs, and the underpricing of initial public offerings, Journal of Finance 44, 421-449. 


\section{Appendix: Sample creation}

We obtain issuance data from Thomson-Reuters SDC Platinum (for both public debt and equity) and Mergent FISD (for public debt). Credit ratings that are not available in SDC and FISD are supplemented by data from S\&P Ratings Xpress and Datastream. Fundamental firm data is obtained from Compustat, and price/return data are obtained from CRSP, Compustat North America, and Compustat Global security pricing files.

We merge the bond and equity issuance samples from SDC and FISD with Compustat, based on the historical CUSIP. Compustat compiles information on non-public firms that are required to file periodic reports with the SEC in three specific cases. It collects information from the firm's $10-\mathrm{K}$ reports if the number of security-holders of record is more than 300 (or 500 if the company does not have significant assets), if a client requests information on the firm (or S\&P believes that the firm will be of importance to clients), or if the firm has a newsworthy event such as transaction activity or other key developments. In addition, Compustat back-fills data during the private period for firms that eventually go public by issuing debt or equity to public investors. For companies that do not issue public equity, if the information is not listed on Compustat for either the year of or prior to the issue date, we fill in missing information by hand-collecting information from the firm's 10-K filings.

We focus on the public debt issuance of corporate bonds and common stock IPOs by private US-based companies, but exclude issuance by financial services firms from both equity and bond samples. We identify the date when a company issues public debt for the first time as the earliest of the first public debt issuance dates in FISD and SDC. We identify the first date of public equity issuance as the earliest date between the IPO date in SDC and the first date with non-missing price data in CRSP and Compustat security pricing data (North America and Global).

Our primary sample consists of private firms that decide to issue public debt for the first time at least 30 days before they issue equity for the first time. Hence, these firms do not have stock price histories on the date of the public debt issuance, both in CRSP and Compustat. Over the 1987-2016 period, this IPDO sample includes 635 issuers in 43 different industries (based on the Fama-French 48 industry classification). 


\begin{tabular}{|c|c|c|c|c|}
\hline Hypotheses & Model & \multicolumn{2}{|c|}{$\begin{array}{c}\text { Likelihood of going public } \\
\text { through }\end{array}$} & Variables \\
\hline Cost of information production & Chemmanur and Fulghieri (1999) & & & \\
\hline Informativeness of financial statements & Ball, Robin, and Sadka (2008) & Higher & Lower & $\begin{array}{l}\text { Age, level of tangible assets, } \\
\text { operating performance (specific } \\
\text { assets are easily collaterizable) }\end{array}$ \\
\hline Private benefits of control & $\begin{array}{l}\text { Boot, Gopalan and Thakor (2006, } \\
\text { 2008) }\end{array}$ & Higher & Lower & $\begin{array}{l}\text { Sponsor backing (Sponsors less } \\
\text { likely to be willing to give up } \\
\text { control after the firm has gone } \\
\text { public) }\end{array}$ \\
\hline Corporate transaction activity & $\begin{array}{l}\text { Hsieh, Lyandres, and Zhdanov } \\
\text { (2011), Celikyurt, Sevilir, and } \\
\text { Shivdasani (2010), Helwege and } \\
\text { Packer (2009) }\end{array}$ & Lower & Higher & $\begin{array}{l}\text { Industry liquidity index as in } \\
\text { Schlingemann, Stulz, and } \\
\text { Walkling (2002) (Equity is more } \\
\text { useful to buy corporate assets or } \\
\text { other firms) }\end{array}$ \\
\hline
\end{tabular}

Table 1: Empirical predictions of the main theories on the market to go public

Description: This table lists our main predictions. Established theories on the market to go public posit three main explanations for the choice of market.

Interpretation: Firms should prefer to go public in debt markets when they are older, have high levels of tangible assets and operating performance, have fewer growth opportunities and when the private benefits of control are high. 


\begin{tabular}{|c|c|c|c|c|c|c|c|c|}
\hline \multirow[b]{2}{*}{ Year } & \multicolumn{2}{|c|}{$\begin{array}{l}\text { Unlisted firms issuing } \\
\text { public debt for the first time } \\
\text { (IPDO) }\end{array}$} & \multicolumn{2}{|c|}{$\begin{array}{c}\text { Unlisted firms issuing } \\
\text { public equity for the first } \\
\text { time (IPO) } \\
\text { (matched on industry) }\end{array}$} & \multicolumn{2}{|c|}{$\begin{array}{l}\text { Unlisted firms issuing public } \\
\text { equity for the first time (IPO) } \\
\text { (matched on industry and size) }\end{array}$} & \multicolumn{2}{|c|}{$\begin{array}{l}\text { Listed firms issuing public debt } \\
\text { for the first time (PFDO) } \\
\text { (matched on industry) }\end{array}$} \\
\hline & $\begin{array}{l}\text { Number } \\
\text { of firms }\end{array}$ & $\begin{array}{l}\text { Amount of } \\
\text { public debt } \\
\text { raised, \$mil. }\end{array}$ & $\begin{array}{l}\text { Number } \\
\text { of firms }\end{array}$ & $\begin{array}{l}\text { Amount of } \\
\text { public equity } \\
\text { raised, \$mil. }\end{array}$ & $\begin{array}{l}\text { Number of } \\
\text { firms }\end{array}$ & $\begin{array}{c}\text { Amount of public } \\
\text { equity raised, } \\
\text { \$mil. }\end{array}$ & $\begin{array}{l}\text { Number of } \\
\text { firms }\end{array}$ & $\begin{array}{l}\text { Amount of } \\
\text { public debt } \\
\text { raised, \$mil. }\end{array}$ \\
\hline 1987 & 34 & 4,317 & 213 & 6,508 & 6 & 432 & 49 & 2,354 \\
\hline 1988 & 36 & 7,376 & 68 & 1,822 & 5 & 25 & 13 & 916 \\
\hline 1989 & 26 & 4,249 & 42 & 1,661 & 3 & 1,146 & 9 & 941 \\
\hline 1990 & 4 & 440 & 21 & 762 & 2 & 24 & 2 & 275 \\
\hline 1991 & 6 & 360 & 32 & 1,618 & 0 & 0 & 4 & 330 \\
\hline 1992 & 25 & 2,755 & 189 & 6,230 & 15 & 941 & 29 & 3,159 \\
\hline 1993 & 36 & 5,761 & 248 & 9,046 & 34 & 2,299 & 56 & 4,190 \\
\hline 1994 & 32 & 3,119 & 192 & 5,514 & 20 & 2,695 & 33 & 3,884 \\
\hline 1995 & 19 & 1,796 & 114 & 6,399 & 12 & 3,836 & 37 & 3,719 \\
\hline 1996 & 40 & 5,719 & 358 & 15,682 & 54 & 4,654 & 51 & 5,232 \\
\hline 1997 & 84 & 12,572 & 307 & 13,097 & 91 & 8,132 & 100 & 7,889 \\
\hline 1998 & 87 & 11,504 & 198 & 15,694 & 63 & 5,155 & 135 & 20,845 \\
\hline 1999 & 35 & 5,821 & 338 & 27,933 & 164 & 17,620 & 66 & 11,599 \\
\hline 2000 & 18 & 2,507 & 190 & 19,401 & 47 & 8,425 & 49 & 10,961 \\
\hline 2001 & 13 & 1,770 & 3 & 1,410 & 6 & 522 & 11 & 5,588 \\
\hline 2002 & 9 & 2,197 & 20 & 2,130 & 13 & 2,146 & 20 & 2,889 \\
\hline 2003 & 15 & 3,312 & 11 & 2,630 & 4 & 959 & 14 & 3,519 \\
\hline 2004 & 17 & 3,125 & 39 & 6,611 & 20 & 3,528 & 36 & 5,667 \\
\hline 2005 & 7 & 1,835 & 18 & 2,614 & 8 & 1,573 & 16 & 1,931 \\
\hline 2006 & 6 & 3,151 & 28 & 2,461 & 3 & 1,050 & 6 & 1,679 \\
\hline 2007 & 2 & 350 & 5 & 852 & 3 & 1,258 & 11 & 2,181 \\
\hline 2010 & 10 & 111 & 47 & 4,998 & 42 & 5,329 & 8 & 1,037 \\
\hline 2011 & 17 & 381 & 44 & 5,960 & 33 & 5,718 & 13 & 3,102 \\
\hline 2012 & 12 & 1,980 & 37 & 6,416 & 28 & 5,763 & 25 & 6,348 \\
\hline
\end{tabular}




\begin{tabular}{|c|c|c|c|c|c|c|c|c|}
\hline 2013 & 8 & 406 & 54 & 6,706 & 46 & 6,640 & 23 & 6,044 \\
\hline 2014 & 14 & 83 & 95 & 12,025 & 87 & 11,725 & 33 & 7,315 \\
\hline 2015 & 14 & 737 & 39 & 6,555 & 39 & 6,555 & 35 & 5,505 \\
\hline 2016 & 9 & 7 & 13 & 1,268 & 2 & 399 & 13 & 2,885 \\
\hline Total & 635 & 87,741 & 2,963 & 194,003 & 850 & 108,549 & 897 & 131,984 \\
\hline
\end{tabular}

Table 2. First public debt vs. first public equity issuance: Number and size of issues, 1987-2016

Description: The primary sample of initial public debt offering (IPDO) firms includes private unlisted firms (with no traded equity in CRSP and Compustat) that issue public debt for the first time. The total amount of debt raised is obtained from Mergent FISD and SDC. The SDC IPO equity issues include records with ipoflag='Yes' and security type of common/ordinary shares. The first IPO sample is a control sample of unlisted firms without public debt outstanding issuing public equity for the first time in the same year and industry. The second IPO sample is a control sample of unlisted firms without public debt outstanding issuing public equity for the first time in the same year, industry, and size quintile. IPO firms in this sample are constrained to have assets at least as large as the assets of the matching IPDO firm in that industry and year. They are not constrained to be listed on Compustat (they may not necessarily have GVKey information). The PFDO sample is a control sample of publicly listed firms that issue public debt for the first time in the same year and industry. Public debt issues include corporate bonds (bond types CDEB, CMTN, CMTZ, CCOV, CP, USBN, CS, CCPI, CPAS) from Mergent FISD and SDC. No firms issued initial public debt offerings in 2008 and 2009. Financial services firms are excluded (SIC in 6000-6999).

Interpretation: This table shows that our sample of IPDO firms is a non-trivial proportion (around 21\%) of all IPO firms that issue equity in the same industry and year. There are no IPDO firms in 2008 and 2009. 


\begin{tabular}{|c|c|c|c|c|c|c|c|}
\hline $\begin{array}{l}\text { Industry-median-adjusted firm } \\
\text { characteristics }\end{array}$ & $\begin{array}{l}\text { IPDO } \\
\text { firms } \\
(1) \\
\end{array}$ & $\begin{array}{l}\text { IPO firms } \\
\text { matched } \\
\text { on } \\
\text { industry } \\
\text { and year } \\
(2) \\
\end{array}$ & $\begin{array}{c}\text { Difference } \\
\text { in medians } \\
\\
\text { (1)-(2) }\end{array}$ & $\begin{array}{l}\text { P-values } \\
\text { (Wilcoxon } \\
\text { test of } \\
\text { medians) }\end{array}$ & $\begin{array}{l}\text { IPO firms } \\
\text { matched } \\
\text { on size, } \\
\text { industry, } \\
\text { and year } \\
\text { (3) }\end{array}$ & $\begin{array}{c}\text { Difference } \\
\text { in medians } \\
\\
(1)-(3)\end{array}$ & $\begin{array}{l}\text { P-values } \\
\text { (Wilcoxon } \\
\text { test of } \\
\text { medians) }\end{array}$ \\
\hline \multicolumn{8}{|l|}{ A. Ownership } \\
\hline Sponsor-backed & 0.70 & 0.48 & 0.22 & 0.00 & 0.55 & 0.15 & 0.00 \\
\hline \multicolumn{8}{|l|}{ B. Age and Size } \\
\hline Age (in years) & 10 & 5 & 5 & 0.00 & 5 & 5 & 0.00 \\
\hline Total assets & 382.4 & 91.4 & 291 & 0.00 & 162.8 & 219.6 & 0.00 \\
\hline Sales & 300.3 & 45.5 & 254.8 & 0.00 & 84.1 & 216.2 & 0.00 \\
\hline \multicolumn{8}{|l|}{ C. Profitability } \\
\hline Operating Cash Flow/Capex & 0.77 & -0.01 & 0.78 & 0.00 & 0.02 & 0.75 & 0.00 \\
\hline ROA & 0.00 & -0.11 & 0.11 & 0.00 & -0.05 & 0.05 & 0.00 \\
\hline Operating ROA & 0.01 & -0.09 & 0.1 & 0.00 & -0.04 & 0.05 & 0.00 \\
\hline \multicolumn{8}{|l|}{ D. Growth opportunities } \\
\hline $\mathrm{R} \& \mathrm{D} /$ Assets & 0.01 & 0.04 & -0.03 & 0.00 & 0.02 & -0.01 & 0.00 \\
\hline Asset tangibility (PPE/Assets) & 0.01 & 0.00 & 0.01 & 0.50 & 0.004 & 0.006 & 0.60 \\
\hline \multicolumn{8}{|l|}{ E. Leverage } \\
\hline Debt/EBITDA & 0.98 & 0.25 & 0.73 & 0.21 & 0.16 & 0.82 & 0.18 \\
\hline Interest Coverage & 0.54 & 0.08 & 0.46 & 0.03 & 0.11 & 0.43 & 0.04 \\
\hline Debt/Book Equity & 0.41 & -0.70 & 1.11 & 0.74 & -2.14 & 2.55 & 0.41 \\
\hline \multicolumn{8}{|l|}{ F. Liquidity } \\
\hline Current Ratio & 0.54 & 1.93 & -1.39 & 0.00 & 1.55 & -1.01 & 0.00 \\
\hline Quick Ratio & 0.54 & 1.91 & -1.37 & 0.00 & 1.53 & -0.99 & 0.00 \\
\hline Cash ratio & 0.55 & 1.98 & -1.43 & 0.00 & 1.59 & -1.04 & 0.00 \\
\hline
\end{tabular}

Table 3. IPDO vs. IPO firms: Comparison of industry-median-adjusted firm characteristics

Description: This table presents industry-median-adjusted average values (except for ownership (unadjusted average values) and age, assets, and sales (unadjusted median values)) for the IPDO and IPO samples described in Table 2. P-values from a Wilcoxon test to test the differences in medians across the two samples are also reported. Sponsor-backed is an indicator variable taking the value 1 if SDC lists the firm as having had a financial sponsor prior to the IPDO date. Age is from 
the Capital IQ Company table (item Year Founded). Assets and sales are AT and SALE from the Compustat Fundamentals (annual) dataset. ROA is the sum of net income after extraordinary items (NI) and interest expense (XINT), scaled by (lagged) assets. Operating ROA is operating income after depreciation (OIADP) scaled by (lagged) assets. R\&D ratios are based on XRD, and PPE/Assets is property, plant and equipment (PPENT) as \% of assets. Debt/EBITDA and Debt/Book equity are based on long-term debt (DLTT); book equity is computed as in Daniel and Titman (2006). Interest coverage is the interest expense (XINT) net of interest income (IDIT) divided by operating cash flow. Net working capital is the difference between current assets (ACT) and current liabilities (LCT). The current ratio is the ratio of current assets to current liabilities, the quick ratio is current assets net of inventories (INVT) scaled by current liabilities, and the cash ratio is cash and short-term investments (CHE) divided by current liabilities (LCT).

Interpretation: This table shows that our sample of IPDO firms is older, larger, more profitable, have fewer growth opportunities, are more likely to be sponsorbacked (have a private equity or venture capital sponsor), are more indebted and have less liquid assets than an equivalent sample of IPO firms issuing in the same industry and year. The results based on means are qualitatively similar. 


\begin{tabular}{|c|c|c|c|c|c|c|}
\hline \multirow{2}{*}{$\begin{array}{l}\text { Variable } \\
\text { Ownership }\end{array}$} & (1) & \multicolumn{4}{|c|}{ Matched on year and industry } & $\begin{array}{l}\text { Matched on } \\
\text { year, size, } \\
\text { and industry } \\
\text { (6) }\end{array}$ \\
\hline & & & & & & \\
\hline Sponsor backed & $\begin{array}{c}0.90 \\
(0.00)\end{array}$ & $\begin{array}{c}0.86 \\
(0.00)\end{array}$ & $\begin{array}{c}0.87 \\
(0.00)\end{array}$ & $\begin{array}{c}0.61 \\
(0.00)\end{array}$ & $\begin{array}{c}0.58 \\
(0.00)\end{array}$ & $\begin{array}{c}0.53 \\
(0.00)\end{array}$ \\
\hline \multicolumn{7}{|l|}{ B. Age and size } \\
\hline $\log$ (assets) & & $\begin{array}{c}0.43 \\
(0.00)\end{array}$ & $\begin{array}{c}0.42 \\
(0.00)\end{array}$ & $\begin{array}{c}0.43 \\
(0.00)\end{array}$ & $\begin{array}{c}0.37 \\
(0.00)\end{array}$ & $\begin{array}{c}0.25 \\
(0.00)\end{array}$ \\
\hline Log (age) & & $\begin{array}{c}0.23 \\
(0.00)\end{array}$ & $\begin{array}{c}0.23 \\
(0.00)\end{array}$ & $\begin{array}{c}0.18 \\
(0.00)\end{array}$ & $\begin{array}{c}0.18 \\
(0.00)\end{array}$ & $\begin{array}{c}0.19 \\
(0.00)\end{array}$ \\
\hline \multicolumn{7}{|l|}{ C. Profitability } \\
\hline ROA & & & $\begin{array}{c}0.26 \\
(0.24)\end{array}$ & $\begin{array}{c}1.68 \\
(0.00)\end{array}$ & $\begin{array}{c}0.65 \\
(0.10)\end{array}$ & $\begin{array}{c}0.26 \\
(0.56)\end{array}$ \\
\hline OCF/Capex & & & & $\begin{array}{c}0.00 \\
(0.93)\end{array}$ & $\begin{array}{c}0.02 \\
(0.03)\end{array}$ & $\begin{array}{c}0.01 \\
(0.34)\end{array}$ \\
\hline$(\mathrm{OCF} /$ Capex $) \times$ Sponsor backed & & & & $\begin{array}{c}0.00 \\
(0.96)\end{array}$ & $\begin{array}{l}-0.03 \\
(0.03)\end{array}$ & $\begin{array}{l}-0.01 \\
(0.33)\end{array}$ \\
\hline \multicolumn{7}{|l|}{ D. Liquidity } \\
\hline Current Ratio & & & & $\begin{array}{l}-0.02 \\
(0.13)\end{array}$ & $\begin{array}{c}0.00 \\
(0.69)\end{array}$ & $\begin{array}{l}-0.01 \\
(0.40)\end{array}$ \\
\hline \multicolumn{7}{|l|}{ E. Leverage } \\
\hline Debt/Assets & & & & $\begin{array}{c}0.81 \\
(0.00)\end{array}$ & $\begin{array}{c}1.88 \\
(0.00)\end{array}$ & $\begin{array}{c}1.88 \\
(0.00)\end{array}$ \\
\hline \multicolumn{7}{|l|}{ F. Growth opportunities } \\
\hline Asset tangibility (PPE/Assets) & & & & & $\begin{array}{c}0.58 \\
(0.01)\end{array}$ & $\begin{array}{c}0.42 \\
(0.09)\end{array}$ \\
\hline $\mathrm{R} \& \mathrm{D} /$ Assets & & & & & $\begin{array}{l}-0.50 \\
(0.57)\end{array}$ & $\begin{array}{l}-1.26 \\
(0.22)\end{array}$ \\
\hline \multicolumn{7}{|l|}{ G. Windows of opportunity } \\
\hline Industry misvaluation & & & & & $\begin{array}{c}0.00 \\
(0.85)\end{array}$ & $\begin{array}{l}-0.03 \\
(0.63)\end{array}$ \\
\hline Equity underpricing & & & & & $\begin{array}{l}-0.14 \\
(0.33)\end{array}$ & $\begin{array}{l}-0.09 \\
(0.50)\end{array}$ \\
\hline Debt underpricing & & & & & $\begin{array}{l}-1.84 \\
(0.23)\end{array}$ & $\begin{array}{l}-2.19 \\
(0.22)\end{array}$ \\
\hline Equity underwriting costs & & & & & $\begin{array}{l}-0.44 \\
(0.00)\end{array}$ & $\begin{array}{l}-0.56 \\
(0.00)\end{array}$ \\
\hline Debt underwriting costs & & & & & $\begin{array}{l}-0.01 \\
(0.01)\end{array}$ & $\begin{array}{l}-0.02 \\
(0.00)\end{array}$ \\
\hline $\begin{array}{l}\text { H. Transaction liquidity } \\
\text { Industry liquidity Index }\end{array}$ & & & & & $\begin{array}{c}0.01 \\
(0.34) \\
\end{array}$ & $\begin{array}{c}0.02 \\
(0.09) \\
\end{array}$ \\
\hline Year Fixed Effects & Yes & Yes & Yes & Yes & Yes & Yes \\
\hline $\mathrm{R}^{2}$ & 0.22 & 0.38 & 0.38 & 0.41 & 0.46 & 0.46 \\
\hline $\mathrm{N}$ & 1,443 & 1,443 & 1,441 & 1,177 & 1,157 & 920 \\
\hline
\end{tabular}

Table 4. Probit model of the choice to go public through debt over equity 
Description: This table reports coefficients from a probit model where the dependent variable is 1 for an IPDO firm and 0 for an IPO firm. Industry misvaluation is computed as in Rhodes-Kropf, Robinson, and Vishwanathan (2005). Specifically, we compute the industry median (in a given month) of the difference between $(\log )$ market equity and book equity in that month for all firms in that industry. Industry misvaluation is the deviation of this median from its long-run mean over the previous 12 months. Equity underpricing is the median first day return of all equity IPOs in the respective Fama-French industry in a given month, while debt underpricing is the 12-month moving average of industry-level median of abnormal individual bond IPO and SEO returns (in excess of the return on the corresponding bond index) over the 7 days from the offering date. Equity underwriting cost is the mean gross spread per share of all equity IPOs in the respective industry in a given month. Debt underwriting cost is the 12-month moving average of the industry-level mean gross spread in a given month. Industry liquidity index is a ratio of the value of corporate control transactions to the total book value of assets of firms in a given industry-year. All other variables are defined in Table 3 . All firm characteristics are industry-adjusted. Standard errors are clustered by year. P-values are reported in parentheses.

Interpretation: This table shows that in a multivariate framework, largely the same results hold as in the univariate framework. IPDO firms are more likely to be sponsor-backed, larger, older, have more tangible assets and are more indebted than their contemporaneous IPO peers. 


\begin{tabular}{lcccc}
\hline \multicolumn{1}{c}{ Sample IPO Characteristics } & $\begin{array}{c}\text { IPDO } \\
\text { firms that } \\
\text { go public }\end{array}$ & $\begin{array}{c}\text { Unlisted firms } \\
\text { without public debt } \\
\text { in place going public } \\
\text { in the same industry- } \\
\text { year }\end{array}$ & $\begin{array}{c}\text { Difference } \\
\text { P- } \\
\text { Value }\end{array}$ \\
\hline First day return (mean) & 0.15 & 0.51 & -0.36 & 0.00 \\
"Hot" IPO indicator variable & 0.71 & 0.73 & -0.02 & 0.00 \\
Sponsor-backed & 0.18 & 0.58 & -0.40 & 0.01 \\
Principal amount raised (\$ mil.) & 120.00 & 60.00 & 60.00 & 0.00 \\
Quote spread (\%, mean) & 1.02 & 0.99 & 0.03 & 0.42 \\
Underwriter effort & & & & \\
Syndicated Indicator variable (1 if yes, 0 otherwise) & 1.00 & 0.98 & 0.02 & 0.01 \\
Number of Managers & 4.00 & 4.00 & 0.00 & 0.00 \\
Underwriter fees & & & & \\
Gross Spread as \% of Principal Amount & & & -0.25 & 0.00 \\
Management fee as \% of Principal Amount & 6.75 & 7.00 & -0.20 & 0.00 \\
Underwriting fee as \% of Principal Amount & 1.41 & 1.61 & -0.18 & 0.00 \\
\hline
\end{tabular}

Table 5. Unlisted firms with and without public debt outstanding: Comparison of terms of subsequent IPO

Description: This table reports the average first day IPO return and binary indicator variables (means) and other IPO characteristics (medians) for firms with existing public debt that went public in our sample and industryyear matched unlisted firms that went public without any public debt outstanding. IPO characteristics are obtained from the SDC equity issuance database. The first day return is the difference between the closing price on the first day of trading and the offer price scaled by the offer price. "Hot" IPO indicator variable equals 1 if the offer price exceeds the original high filing price in the prospectus and 0 otherwise. The syndicated indicator variable takes the value 1 if the IPO is syndicated and 0 otherwise. Quote spread is the defined as the bid-ask spread scaled by the bid-ask midpoint (it is set to missing if it is greater than $1 / 2$ of bid-ask midpoint). The average quote spread is computed over 60 days following the IPO. The rest of the variables are self-explanatory. The last column reports p-values for the t-test (for means) and Wilcoxon non-parametric test (for medians).

Interpretation: This table shows that our sample of IPDO firms have significantly lower underpricing and underwriting fees if they go public than an equivalent sample of IPO firms issuing in the same industry and year. Firms who have gone public through debt have reduced their levels of information asymmetry and this shows up in the level of underpricing they receive and in the fees they are charged when they issue public equity. 


\begin{tabular}{|c|c|c|c|c|}
\hline \multirow[b]{2}{*}{ Variable } & \multicolumn{3}{|c|}{ Matched on industry and year } & \multirow{2}{*}{$\begin{array}{c}\begin{array}{c}\text { Matched on } \\
\text { industry, size, } \\
\text { and year }\end{array} \\
\text { (4) }\end{array}$} \\
\hline & (1) & (2) & (3) & \\
\hline IPDO firm indicator variable & $\begin{array}{l}-0.17 \\
(0.03)\end{array}$ & $\begin{array}{l}-0.18 \\
(0.02)\end{array}$ & $\begin{array}{l}-0.19 \\
(0.02)\end{array}$ & $\begin{array}{l}-0.18 \\
(0.09)\end{array}$ \\
\hline \multicolumn{5}{|l|}{ Controls } \\
\hline Sponsor-backed IPO & $\begin{array}{c}0.20 \\
(0.00)\end{array}$ & $\begin{array}{c}0.21 \\
(0.00)\end{array}$ & $\begin{array}{c}0.21 \\
(0.00)\end{array}$ & $\begin{array}{c}0.05 \\
(0.63)\end{array}$ \\
\hline Log Assets & $\begin{array}{c}0.01 \\
(0.64)\end{array}$ & $\begin{array}{c}0.03 \\
(0.18)\end{array}$ & $\begin{array}{c}0.01 \\
(0.83)\end{array}$ & $\begin{array}{c}0.00 \\
(0.93)\end{array}$ \\
\hline Log Age & $\begin{array}{l}-0.10 \\
(0.00)\end{array}$ & $\begin{array}{l}-0.11 \\
(0.00)\end{array}$ & $\begin{array}{l}-0.10 \\
(0.00)\end{array}$ & $\begin{array}{l}-0.02 \\
(0.44)\end{array}$ \\
\hline ROA & $\begin{array}{l}-0.14 \\
(0.22)\end{array}$ & $\begin{array}{l}-0.17 \\
(0.15)\end{array}$ & $\begin{array}{l}-0.16 \\
(0.19)\end{array}$ & $\begin{array}{l}-1.06 \\
(0.01)\end{array}$ \\
\hline OCF/Capex & $\begin{array}{c}0.05 \\
(0.58)\end{array}$ & $\begin{array}{c}0.06 \\
(0.49)\end{array}$ & $\begin{array}{c}0.12 \\
(0.16)\end{array}$ & $\begin{array}{l}-0.31 \\
(0.50)\end{array}$ \\
\hline PPE/Assets & $\begin{array}{l}-0.32 \\
(0.15)\end{array}$ & $\begin{array}{l}-0.32 \\
(0.16)\end{array}$ & $\begin{array}{l}-0.28 \\
(0.21)\end{array}$ & $\begin{array}{l}-0.26 \\
(0.34)\end{array}$ \\
\hline Current Ratio $(\times 100)$ & $\begin{array}{c}0.02 \\
(0.01)\end{array}$ & $\begin{array}{c}0.01 \\
(0.01)\end{array}$ & $\begin{array}{c}0.01 \\
(0.01)\end{array}$ & $\begin{array}{c}0.01 \\
(0.08)\end{array}$ \\
\hline Log IPO Amount Raised & $\begin{array}{c}0.06 \\
(0.13)\end{array}$ & $\begin{array}{c}0.07 \\
(0.12)\end{array}$ & $\begin{array}{c}0.12 \\
(0.01)\end{array}$ & $\begin{array}{c}0.09 \\
(0.19)\end{array}$ \\
\hline Syndicated Indicator variable & & $\begin{array}{c}0.24 \\
(0.00)\end{array}$ & $\begin{array}{c}0.21 \\
(0.01)\end{array}$ & $\begin{array}{c}0.41 \\
(0.00)\end{array}$ \\
\hline Number of managers & & $\begin{array}{l}-0.03 \\
(0.01)\end{array}$ & $\begin{array}{l}-0.03 \\
(0.01)\end{array}$ & $\begin{array}{l}-0.04 \\
(0.03)\end{array}$ \\
\hline Gross Spread as \% of amount raised & & & $\begin{array}{c}0.38 \\
(0.01)\end{array}$ & $\begin{array}{c}0.00 \\
(0.99)\end{array}$ \\
\hline Adjusted $\mathrm{R}^{2}$ & 0.12 & 0.12 & 0.13 & 0.15 \\
\hline $\mathrm{N}$ & 455 & 455 & 455 & 207 \\
\hline
\end{tabular}

Table 6. Relative underpricing of IPDO firms vs. IPO firms at subsequent IPO

Description: This table reports coefficients from OLS regressions of the IPO first-day return (IPO underpricing proxy) for the IPDO firms that issue public equity during the sample period and firms going public without public debt in place in the same industry and year. IPO characteristics are obtained from the SDC equity issuance database. The IPO of the IPDO firm indicator variable equals 1 if an IPO is by an IPDO firm with existing public debt and 0 if it is an IPO by the firm without public debt outstanding, issuing public equity in the same industry and year. Firm characteristics are industry-adjusted and defined as in Table 3. The syndicated indicator variable is 1 if an IPO is syndicated and 0 otherwise. Other deal variables are self-explanatory. P-values are reported in parentheses. 
Interpretation: This table shows that the IPDO indicator variable continues to be negative and significant in a multivariate framework after controlling for other control variables. As in the previous table, this suggests that going public initially through debt reduces information asymmetry and underpricing when the firms issue public equity later. 


\section{Panel A. Number of firms issuing equity or debt}

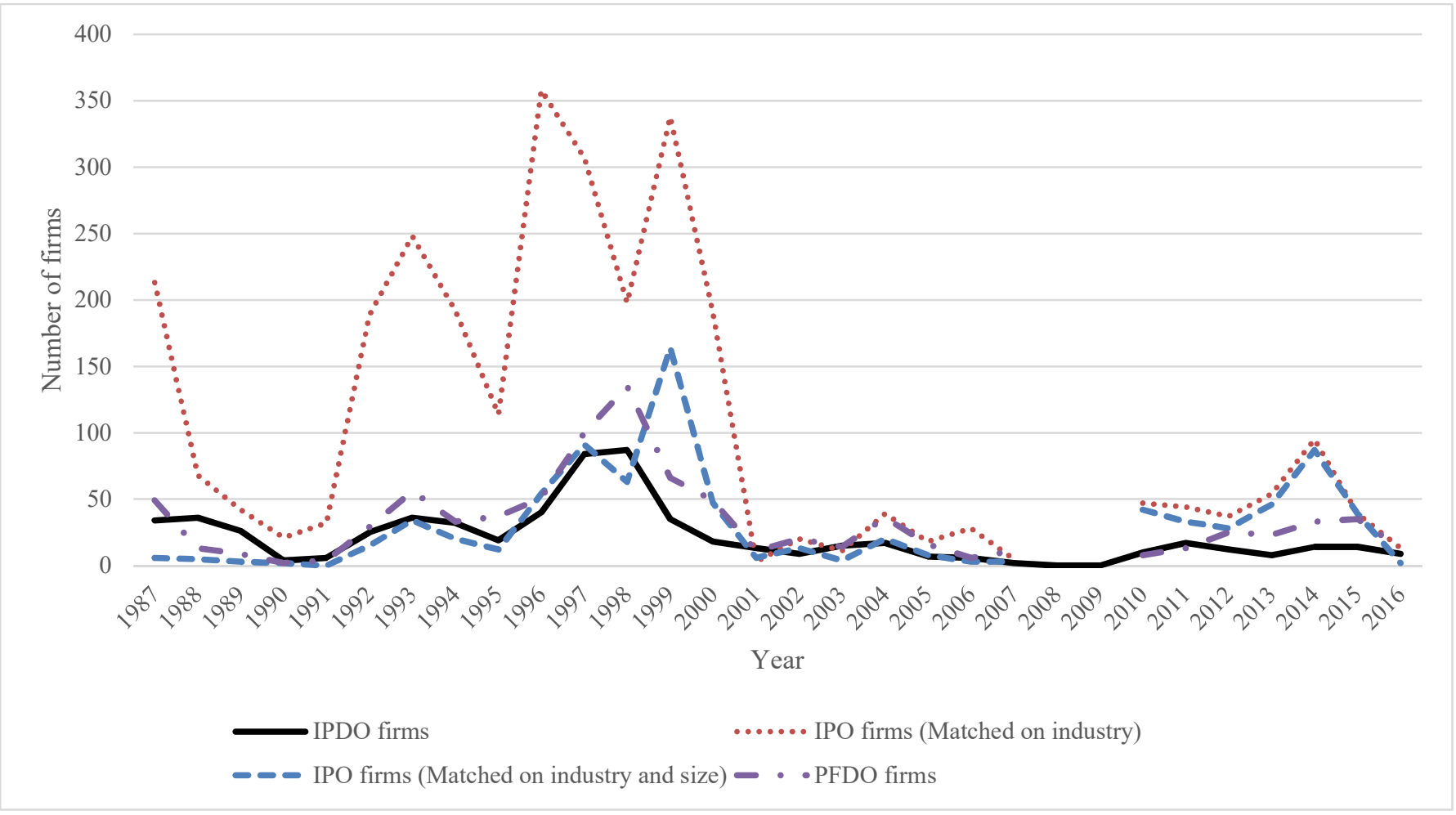

\section{Panel B. Size of issuance by year}

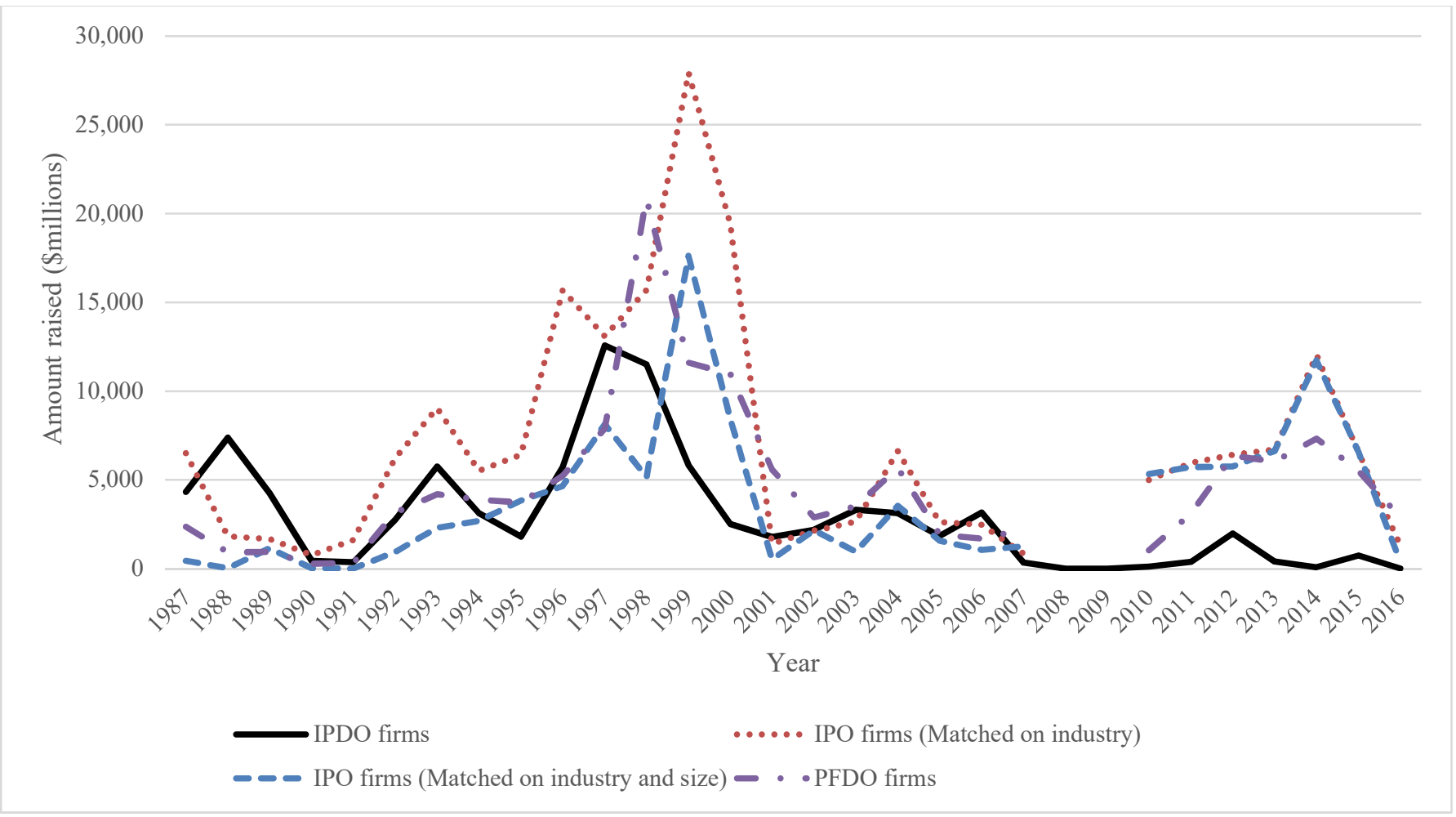

Figure 1. Patterns of issuance

Description: (Panel A) Number of firms issuing equity or debt. This panel plots the number of IPDO firms, industrymatched and industry-size matched IPOs and PFDO firms by year. The correlations between the IPDO sample and the 
IPO samples matched on industry, and matched on industry and size, are both positive and significant at 0.71 and 0.47 respectively. The correlation between the IPDO sample and PFDO sample is higher at 0.89. (Panel B) This panel plots the dollar amount issued by IPDO firms, industry-matched and industry-size matched IPOs and PFDO firms by year. The correlations between the IPDO sample and the IPO samples matched on industry, and matched on industry and size, are both positive and significant at 0.46 and 0.17 respectively. The correlation between the IPDO sample and PFDO sample is higher at 0.53 .

Interpretation: Though there appears to be a significant time-series component to when firms tap the capital markets, through debt or equity, there appear to be few differences in the choice of market to do so. 